\title{
Human herpesvirus-6: neurologic implications of a newly-described viral pathogen
}

\author{
David W Kimberlin ${ }^{1,3}$ and Richard J Whitley ${ }^{1,2,3}$ \\ ${ }^{1}$ Division of Clinical Virology; ${ }^{2}$ Department of Microbiology, and Medicine; ${ }^{3}$ Department of Pediatrics, The University of \\ Alabama at Birmingham, Birmingham, Alabama, USA
}

\begin{abstract}
Discovered only 12 years ago, human herpesvirus-6 (HHV-6) has been associated with central nervous system (CNS) findings such as febrile seizures, encephalitis, meningitis, and possibly multiple sclerosis. These manifestations have been reported in both immunocompetent and immunocompromised individuals. The applications of such sophisticated laboratory tools as polymerase chain reaction, in situ hybridization, immunohistochemical staining, and representational difference analysis have expanded knowledge of the spectrum of CNS disease attributable to HHV-6 while delineating pathogenic mechanisms of both primary HHV-6 infection and reactivation from latency. This article reviews existing knowledge of the CNS manifestations of HHV-6, focusing on both clinical aspects of HHV-6 infection and its pathogenesis on neurologic diseases.
\end{abstract}

Keywords: human herpesvirus-6; HHV-6; seizure; encephalitis; viral meningitis; multiple sclerosis

\section{Introduction}

In 1986, a novel virus was isolated from six patients with lymphoproliferative syndromes, two of whom were also infected with the human immunodeficiency virus (HIV) (Salahuddin et al, 1986). Molecular and structural characterization indicated that it was a herpesvirus, though serologic and genomic analyses confirmed it to be distinct from all previously identified human herpesviruses (Josephs et al, 1986). Due to the initial belief that the new virus selectively infected freshly isolated human B cells, the virus was given the name human B-lymphotropic virus (HBLV) (Salahuddin et al, 1986). Subsequent investigation revealed a broader cell tropism, with notable T-cell lymphotropism (Lusso et al, 1988). For this reason, current nomenclature refers to this virus as human herpesvirus-6 (HHV-6).

With the discovery of HHV-6 in AIDS patients, initial investigation of possible diseases resulting from HHV-6 infection focused on its role as a possible pathogen or co-factor in $\mathrm{HIV}$-infected

Correspondence: DW Kimberlin, 1600 Seventh Avenue South, Suite 616, Birmingham, Alabama 35233, USA

Received 16 April 1998; revised 27 May 1998; accepted 28 May 1998 persons. As several researchers investigated and characterized HHV-6 in HIV-infected adults, Yamanishi et al, (1988) pursued its association with disease in immunocompetent children. In 1988, Yamanishi discovered that HHV-6 caused the very common childhood disease exanthem subitum (roseola infantum). Indeed, HHV-6 proved to be the most ubiquitous of all human herpesviruses (Farr et al, 1990). Neurologic manifestations of exanthem subitum have been described since the beginning of this century. Over the past decade, investigations have confirmed and expanded the clinical associations of HHV-6 to include such neurologic manifestations as febrile seizures, encephalitis, meningitis, and possibly multiple sclerosis.

This article will review the current knowledge of the biology and pathology of HHV-6 infection. Proven and suspected associations with neurologic diseases and sequelae will be discussed.

\section{Virology}

Human herpesvirus-6 is a member of the Herpesviridae family. Genomic analysis places HHV-6 among the $\beta$-herpesviruses, along with cytomegalovirus 
(CMV) and human herpesvirus-7 (HHV-7). On the basis of DNA restriction analysis, in vitro tropism studies, and antigenic relationships defined by reactivities of monoclonal antibodies, HHV-6 can be separated into two variants, designated variant $A$ (HHV-6A) and variant B (HHV-6B) (Ablashi et al, 1993). Characteristic HHV-6A strains include GS (the original strain) and U 1102 (isolated from a Ugandan AIDS patient) (Salahuddin et al, 1986; Downing et al, 1987). The prototypic HHV-6B strain is Z 29, isolated from a Zairian AIDS patient (Lopez et al, 1988). Variant B strains can be further characterized as belonging to one of two groups, designated group 1 and group 2. The intravariant nucleotide sequence homology ranges from 97$100 \%$, while intervariant homology ranges from 94-96\% (Aubin et al, 1991; Teo et al, 1991; Aubin et al, 1993; Gompels et al, 1993; Chou and Marousek, 1994).

Though the first isolate of HH-6 (GS) was a variant A strain, only HHV-6B strains have been definitively proven to cause disease (exanthem subitum in childhood, as described below). At the current time, it is unclear if HHV-6A causes any disease. Variant A strains of HHV-6 are mainly isolated from AIDS patients or persons with lymphoproliferative disorders, while HHV-6B strains are primarily recovered from patients with exanthem subitum. Investigations into the clinical consequences of HHV-6A and -6B infections are further hampered by the lack of reliable methods for distinguishing between antibody responses to HHV-6A and HHV$6 B$.

\section{In vitro biologic properties}

Human herpesvirus-6 exhibits predominantly CD4 T-lymphocyte tropism (Lusso et al, 1988; Takahashi et al, 1989). The HHV-6 receptor has not been identified, though it has been definitively proven to not be the CD4 molecule (Lusso et al, 1989). Natural killer cells can also be infected with HHV6 (Lusso et al, 1993). Efficient HHV-6 replication in primary cell culture requires both prior mitogen activation of primary $\mathrm{T}$ cells, as provided by phytohemagglutinin (PHA) (Salahuddin et al, 1986; Lopez et al, 1988), and full progression of the cell cycle, as demonstrated by the requirement for interleukin-2 (IL-2) (Black et al, 1989; Frenkel et al, 1990). Both HHV-6A and HHV-6B strains have been adapted by serial passage to replicate in continuous cell lines. However, strains of HHV-6B replicate less readily in continuous cell lines than do those of HHV-6A (Black et al, 1989). Established human cell lines that support HHV-6A replication include those of $\mathrm{T}$ cell (including the T-lymphoblastoid cell line HSB-2), B cell, megakaryocyte, and glial cell lineages, as well as transformed cervical epithelial cells (Pellett and
Black, 1996). Human herpesvirus-6B strains replicate well in the Molt-3 $\mathrm{T}$ cell line and the $\mathrm{T}$ cell lymphoma line MT-4 (Black et al, 1989; Ablashi et al, 1991).

In vitro evidence exists supporting the possible neurotropism of HHV-6. Human herpesvirus-6 is tropic for glioblastoma cell lines (Ablashi et al, 1988) and for embryonic glia (Tedder et al, 1987). The SF strain of HHV-6B replicates at low levels persistently in the neuroblastoma cell line SK-NMC (Levy et al, 1990a). Furthermore, both HHV-6A and HHV-6B variants infect primary human fetal astrocytes in cell culture (He et al, 1996). However, no findings of HHV-6 infection of primary oligodendrocytes or primary neurons in vitro have been reported in the literature to date.

\section{Epidemiology}

Incidence and prevalence of infection

Seroprevalence studies of HHV-6 infection have demonstrated remarkable reproducibility from widely separated regions of the globe. With rare exceptions (Yadav et al, 1990), the prevalence of antibodies to HHV-6 is high among populations throughout the world. Epidemiologic studies in normal children have shown that the vast majority of primary HHV-6 infections occur within the first year of life (Yoshikawa et al, 1989; Farr et al, 1990). Human herpesvirus-6 IgG can be detected in more than $90 \%$ of neonates (Knowles and Gardner, 1988; Leach et al, 1992), reflecting both the high seroprevalence of HHV-6 among adults (Brown et al, 1988b; Ranger et al, 1991; Leach et al, 1992) and the active transport of HHV-6 IgG across the placenta (Yoshikawa et al, 1989). The prevalence of HHV-6 IgG drops significantly by $4-6$ months of life as maternal antibodies decline, then increases through the third year of life and remains high into adulthood (Yoshikawa et al, 1989; Farr et al, 1990). More than $90 \%$ of immunocompetent children become infected with HHV-6 by 12 months of life (Leach et al, 1992), and virtually $100 \%$ acquire infection by 3 years of age (Brown et al, 1988b).

Recent data suggest that HHV-6 variants A and B may differ with respect to their geographical distributions (Kasolo et al, 1997). In the United States, variant B strains predominate in children (Dewhurst et al, 1993), whereas variant A strains have mostly been isolated from adult AIDS patients from Africa (Downing et al, 1987; Tedder et al, 1987). However, a recent study reported that HHV-6 variant A accounted for $44 \%$ of all HHV-6 isolates obtained from Zambian infants experiencing their first febrile episode, a finding dramatically different from the United States' profile of less than 3\% (Kasolo et al, 1997). Additional investigations are needed to further define these possible geographic differences throughout the world. 


\section{Transmission}

Though the mode(s) of transmission of HHV-6 has yet to be definitively proven, most children probably acquire infection through contact with the secretions of adult caretakers shedding the virus in saliva (Fox et al, 1990; Gopal et al, 1990; Harnett et al, 1990; Krueger et al, 1990; Levy et al, 1990b). Reports of isolation of HHV-6 from the saliva of healthy adults (Harnett et al, 1990; Levy et al, 1990b) and patients infected with HIV (Levy et al, 1990b) document salivary shedding in more than $85 \%$ of persons. Human herpesvirus-6 DNA can be detected by polymerase chain reaction (PCR) in saliva or PBMCs of $90 \%$ of healthy individuals (Cone et al, 1993). Using in situ hybridization and immunohistochemical staining, HHV-6 DNA and HHV-6 protein expression have been demonstrated in tissue from submandibular glands (Fox et al, 1990), parotid glands (Fox et al, 1990), salivary glands (Krueger et al, 1990), and bronchial glands (Krueger et al, 1990). Breast milk is unlikely to be an important source of early HHV-6 infection (Takahashi et al, 1988).

\section{Pathogenesis}

Analysis of pathologic specimens confirms that HHV-6 can infect a wide variety of cell and tissue types. During acute infection, viral replication occurs within lymphocytes, macrophages, histiocytes, endothelial cells and epithelial cells, with $\mathrm{CD}^{+} \mathrm{T}$ lymphocytes being the predominant target cell type in the blood. The cell target of HHV-6 within the oropharynx during primary infection remains under investigation.

Direct evidence of persistence of HHV-6 infection is provided in comparisons of serial isolates obtained from an immunocompromised bone marrow transplant (BMT) recipient (Yoshikawa et al, 1992a). Specifically, restriction endonuclease analyses of pre- and post-BMT HHV-6 isolated from a child with leukemia were identical, suggesting persistence of HHV-6 infection or reactivation from latency. Additionally, HHV-6 DNA can be demonstrated by PCR in as many as 90\% of PBMC specimens from healthy adults (Jarrett et al, 1990; Cone et al, 1993; Cuende et al, 1994), a frequency much higher than that detected by viral culture from normal adults. The relatively frequent detection of HHV-6 antigens in normal salivary glands (Fox et al, 1990; Krueger et al, 1990), lymph node tissue (Levine et al, 1992) and neurons and glial cells of the brain (Challoner et al, 1995) also suggest that the virus can persistently infect cells, or can establish latency and subsequently reactivate. Evidence for persistence of HHV-6 within the CNS is presented below (Kondo et al, 1993; Caserta et al, 1994).

\section{Clinical manifestations of HHV-6}

Primary infection in immunocompetent patients

Children The only disease for which HHV-6 has been shown definitively to be the causative agent is exanthem subitum (Yamanishi et al, 1988; Ueda et al, 1989; Yoshiyama et al, 1990). A common disease of childhood, exanthem subitum was first described in 1910 by Zahorsky, who termed the illness roseola infantum (Berenberg et al, 1949). In 1921, Veeder helped confirm this syndrome as a specific pathologic entity and suggested the name exanthem subitum (Berenberg et al, 1949). Illness is characterized by a constant or intermittent, high fever to $104-105^{\circ} \mathrm{F}$ for $3-5$ days in a patient who appears relatively well. The patient may have mild catarrhal inflammation of the pharyngeal mucosa and otitis media. Coincident with or immediately following the return of the temperature to normal, a rose pink macular rash appears predominantly on the neck and trunk, although it may involve the proximal extremities, postaural regions and face. The rash is not pruritic, does not desquamate and fades after $24-48 \mathrm{~h}$.

As early as 1950, a possible viral etiology of exanthem subitum was proposed (Kempe et al, 1950; Hellstrom and Vahlquist, 1951). It was not until 1988, however, that Yamanishi and colleagues definitively proved the viral pathogenesis of exanthem subitum by successfully isolating HHV-6 from the peripheral blood lymphocytes of four infants in the febrile phase of exanthem subitum and by documenting seroconversion to HHV-6 in these patients (Yamanishi et al, 1988). Subsequent studies have confirmed exanthem subitum as a manifestation of primary HHV-6 infection (Ueda et al, 1989; Yoshiyama et al, 1990). Variant B of HHV-6 is responsible for essentially all exanthem subitumassociated HHV-6 infections (Dewhurst et al, 1992; Dewhurst et al, 1993).

At least half of first episodes of fever during infancy are due to primary HHV-6 infection (Okada et al, 1993; Asano et al, 1994). Approximately 60\% of primary HHV-6 infections in Japan are associated with a rash and result in the clinical diagnosis of exanthem subitum (Kusuhara et al, 1992), while only $9-40 \%$ of children in the United States with primary HHV-6 infection have an illness clinically compatible with exanthem subitum (Pruksananonda et al, 1992; Segondy et al, 1992; Portolani et al, 1993; Hall et al, 1994). The reasons for this geographic discrepancy are not fully understood. Atypical presentations of primary HHV-6 infection include exanthem subitum without fever (Asano et al, 1989a), exanthem subitum without rash (Suga et al, 1989; Pruksananonda et al, 1992; Segondy et al, 1992; Portolani et al, 1993) and exanthem subitum at extremely young ages (Kawaguchi et al, 1992).

Two recent large reports have prospectively evaluated primary HMV-6 infection in infants and young children (Pruksananonda et al, 1992; Hall et 
al, 1994). In the first, 243 children 2 years of age or younger who had acute febrile illness were evaluated for HHV-6 infection (Pruksananonda et al, 1992). In 34 (14\%) of the 243 subjects, HHV-6 was cultured from the peripheral blood obtained at the time of the initial visit. Children with HHV-6 viremia were irritable and had high fevers and inflammation of the tympanic membranes. Only three $(9 \%)$ of the 34 patients with HHV-6 viremia presented with or subsequently developed disease clinically compatible with exanthem subitum. Subjects who were HHV-6 culture-positive had significantly lower average white blood cell counts at presentation when compared with HHV-6 culture-negative patients $\left(8.9 \times 10^{9}\right.$ versus $13.2 \times 10^{9}$ per liter, $P<0.001)$. All but one of the strains of HHV-6 cultured were variant $B$, with the single aberrant culture yielding virus that contained a mixture of A and B variant genotypes (Dewhurst et al, 1993).

In the second large prospective study, 2587 children under 3 years of age presenting to the emergency department with acute illnesses, both febrile and afebrile, were evaluated for HHV-6 infection by PBMC culture, serologic testing and PCR (Hall et al, 1994). This investigation found HHV-6B to be a major cause of emergency room (ER) visits, febrile seizures and hospitalizations. Specifically, $160(9.7 \%)$ of the 1653 infants and young children with acute febrile illnesses had primary HHV-6 infection. While ranging in age from 2 weeks to 25 months, $23 \%$ of these patients were under 6 months of age. Human herpesvirus-6 infections accounted for $20 \%$ of all visits to the emergency department for febrile illnesses among children 6 to 12 months of age. Of the 160 infants and young children with acute HHV-6 infections, 21 (13\%) required hospitalization.

Adults With virtually all children acquiring HHV6 early in childhood, primary HHV-6 infection in adults is rarely documented or reported. When it occurs, however, such clinical conditions as lymphadenopathy (Niederman et al, 1988; StettnerGloning et al, 1992), heterophile-negative mononucleosis (Niederman et al, 1988; Steeper et al, 1990; Akashi et al, 1993) and hepatitis (Dubedat and Kappagoda, 1989; Sobue et al, 1991) can result. Human herpesvirus-6 also has been implicated in histiocytic necrotizing lymphadenitis (Kikuchi's disease) (Niederman et al, 1988) and sinus histiocytosis with massive lymphadenopathy (RosaiDorfman disease) (Levine et al, 1992), though its precise role in these conditions, if any, remains to be determined.

\section{Central nervous system (CNS) involvement}

Acute CNS disease Central nervous system manifestations of exanthem subitum were recognized long before the viral etiology was definitively proven to be HHV-6. Symptoms and signs of patients in these early reports included bulging fontanels, irritability, febrile seizures, meningoencephalitis and residual encephalopathy (Berenberg et al, 1949; Posson, 1949; Moller, 1956; Burnstine and Paine, 1959). Following the identification of HHV-6 as the causative agent of exanthem subitum, many additional instances of CNS involvement in primary HHV-6 infection have been reported (Ishiguro et al, 1990; Asano et al, 1991a; Huang et al, 1991; Asano et al, 1992; Segondy et al, 1992; Yoshikawa et al, 1992b; Kondo et al, 1993; Suga et al, 1993; Caserta et al, 1994; Hall et al, 1994; Ward and Gray, 1994; McCullers et al, 1995). Association of such neurologic findings with HHV-6 is suggested by the concomitant identification of virus by culture from PBMCs, by seroconversion, or, less commonly, by detection of the viral genome in CSF by PCR (Ishiguro et al, 1990; Asano et al, 1992; Yamanishi et al, 1992; Yoshikawa et al, 1992b; Caserta et al, 1994; Ward and Gray, 1994).

\section{Association of HHV-6 with seizures}

In the large series of 2587 infants and young children discussed above, the principal complication of primary HHV-6 infection was seizures (Hall et al, 1994). Of the $160 \mathrm{HHV}-6$-positive patients, 21 $(13 \%)$ had seizures. In comparison, 9\% of HHV-6negative children under 24 months of age with febrile illnesses experienced seizures. While differences in these two comparative groups are not statistically significant $(P=0.18)$, analysis of subpopulations of HHV-6-positive and HHV-6-negative patients did reveal significant findings: eight (36\%) of $22 \mathrm{HHV}-6$-positive infants $12-15$ months of age had seizures, as compared to $17(13 \%)$ of $131 \mathrm{HHV}-$ 6 -negative infants of the same age $(P=0.001$; odds ratio, 0.26; 95 percent confidence interval, 0.09 to 0.8) (Hall et al, 1994).

Of the 21 HHV-6-positive patients with seizures, all were febrile at the time of the convulsion. Nine $(43 \%)$ of the 21 experienced seizures late in the febrile course (on days 2-9), and in three children the seizures were prolonged and recurred within three days. Overall, HHV-6 accounted for $31 \%$ of febrile seizures in children under two years of age (Hall et al, 1994).

The complete lack of an inflammatory response in the cerebrospinal fluid (CSF) was notable in all HHV-6-positive patients, both with and without seizures, on whom a lumbar puncture was performed. All patients on whom nontraumatic lumbar punctures were obtained had normal cerebrospinal fluid (CSF) indices, including white blood cell counts, glucose and protein. Human herpesvirus-6 DNA was detected by PCR in seven of 29 samples tested, including two of seven samples from children with seizures. No CSF sample grew HHV6 in viral culture (Hall et al, 1994). 
In another report, the role of HHV-6 in febrile seizures was evaluated in 42 children (Barone et al, 1995). All had first-time febrile convulsions. A total of $11(26 \%)$ of the 42 children had virologic or serologic evidence of acute HHV-6 infection, a finding that is comparable to the $31 \%$ discussed above.

Detection of HHV-6 DNA in the CSF of children with repeated febrile seizures and after primary infection suggests that viral persistence and reactivation within the CNS can occur (Kondo et al, 1993; Caserta et al, 1994). In a study of 172 children under 3 years of age, the neuroinvasiveness of HHV-6 (defined as the presence of viral DNA in the CSF) was documented in seven $(23 \%)$ of 30 children with acute HHV-6 infection documented by viremia and seroconversion and in $65(46 \%)$ of the 142 children with past HHV-6 infection (Caserta et al, 1994). These data suggest that the CNS may be a reservoir of latent or persistent HHV-6 infection. Another report documented HHV-6 DNA in the CSF of seven $(70 \%)$ of 10 children with exanthem subitum (Yamanishi et al, 1992). However, in this study patients with exanthem subitum were chosen for inclusion based upon the presence of such neurologic symptoms as febrile convulsions, vomiting, or bulging of the anterior fontanel during the febrile phase of illness, thus introducing the possibility of overstating the actual frequency by sampling bias. Nevertheless, one can conclude that neuroinvasion with primary HHV-6 infection occurs frequently, with the risk ranging from $23 \%$ (Caserta et al, 1994) to $70 \%$ (Yamanishi et al, 1992).

The presence of the HHV-6 DNA in the central nervous system (CNS) at the time of the initial HHV6 infection has been reported to increase the risk of recurrence of febrile convulsions (Kondo et al, 1993). Other reports, however, have found that children whose first febrile seizure is caused by primary HHV-6 infection do not demonstrate an increased risk for recurrent seizures when compared with children whose first febrile seizures are from other etiologies (Jee et al, 1998). Additional investigations into the neurotropic potential of HHV-6 during primary infection and the possible consequences of such neuroinvasion are required to address this discrepancy.

Association of HHV-6 with meningitis/encephalitis Human herpesvirus-6 has been implicated as a cause of meningitis and encephalitis in children (Ishiguro et al, 1990; Huang et al, 1991; Asano et al, 1992; Yoshikawa et al, 1992b; Knox et al, 1995; McCullers et al, 1995; Yanagihara et al, 1995) and adults (Sloots et al, 1993; Drobyski et al, 1994; McCullers et al, 1995). Most descriptions in the literature are case reports. In one large series, though, the variant B of HHV-6 was associated with focal encephalitis (McCullers et al, 1995). In this report, CSF from 138 patients with clinical or laboratory evidence of encephalitis was analyzed retrospectively by PCR. Human herpesvirus-6 DNA was detected in the CSF of nine (7\%) of the 138 patients and no other proven etiology for disease existed for any of the patients evaluated. No significant differences could be demonstrated in clinical presentation, laboratory findings, or neurodiagnostic imaging results between the nine patients with confirmed HHV-6 infection and the 129 patients without evidence of HHV-6 infection. Cerebrospinal fluid indices from the two groups were similar (HHV-6-positive patients: average WBC count of $81 / \mathrm{mm}^{3}$, average protein concentration of $57 \mathrm{mg} / \mathrm{dL}$; HHV-6-negative patients: average WBC count of 184 cells $/ \mathrm{mm}^{3}$, average protein concentration of $86 \mathrm{mg} / \mathrm{dL})$. Five of the nine patients were under 18 years of age. Four of the nine patients had abnormal neuroimaging studies, with two demonstrating focal lesions (parietal lobe and fronto-temporal area). Electroencephalograms were performed in eight of the nine patients and were abnormal in seven of them. Four of the nine patients recovered fully; three had mild to moderate neurologic impairment; one patient had a persistent, severe, focal seizure disorder; and one patient died of complications of his neurologic disease (McCullers et al, 1995).

In another large investigation of 50 patients with meningitis or encephalitis, $10(20 \%)$ had increased intrathecal anti-HHV-6 early antigen IgM or IgG (Patnaik and Peter, 1995). None of the 50 control patients had intrathecal HHV-6 antibody. For the ten HHV-6-positive patients, none had elevations of intrathecal antibody levels to 26 other viruses, including herpes simplex virus, Epstein-Barr virus, CMV, varicella-zoster virus, arboviruses, echoviruses, measles virus and mumps virus (Patnaik and Peter, 1995).

Human herpesvirus-6 has been demonstrated by immunohistochemical staining of postmortem brain tissue from a child with HIV who dies of fulminant encephalitis (Knox et al, 1995) and at autopsy of an adult bone marrow transplant patient with encephalitis (Yanagihara et al, 1995). In the former case, HHV-6-infected cells were demonstrated in the gray matter, mostly in astrocytes but also in oligodendrocytes and neurons (Knox et al, 1995). In the latter case, HHV-6-infected cells were demonstrated in neurons of affected gray matter and in astrocytes from areas of white matter lesions, where areas of demyelination were observed (Yanagihara et al, 1995). Figure 1 presents a single photon emission computed tomography (SPECT) from the latter patient, showing a hypoperfused area of the left hemisphere (Yanagihara et al, 1995).

Human herpesvirus-6 was present in high amounts in multifocal demyelinating white matter lesions of an immunocompetent young woman with fulminant encephalomyelitis (Novoa et al, 1997). Human herpesvirus-6 was identified by PCR and 

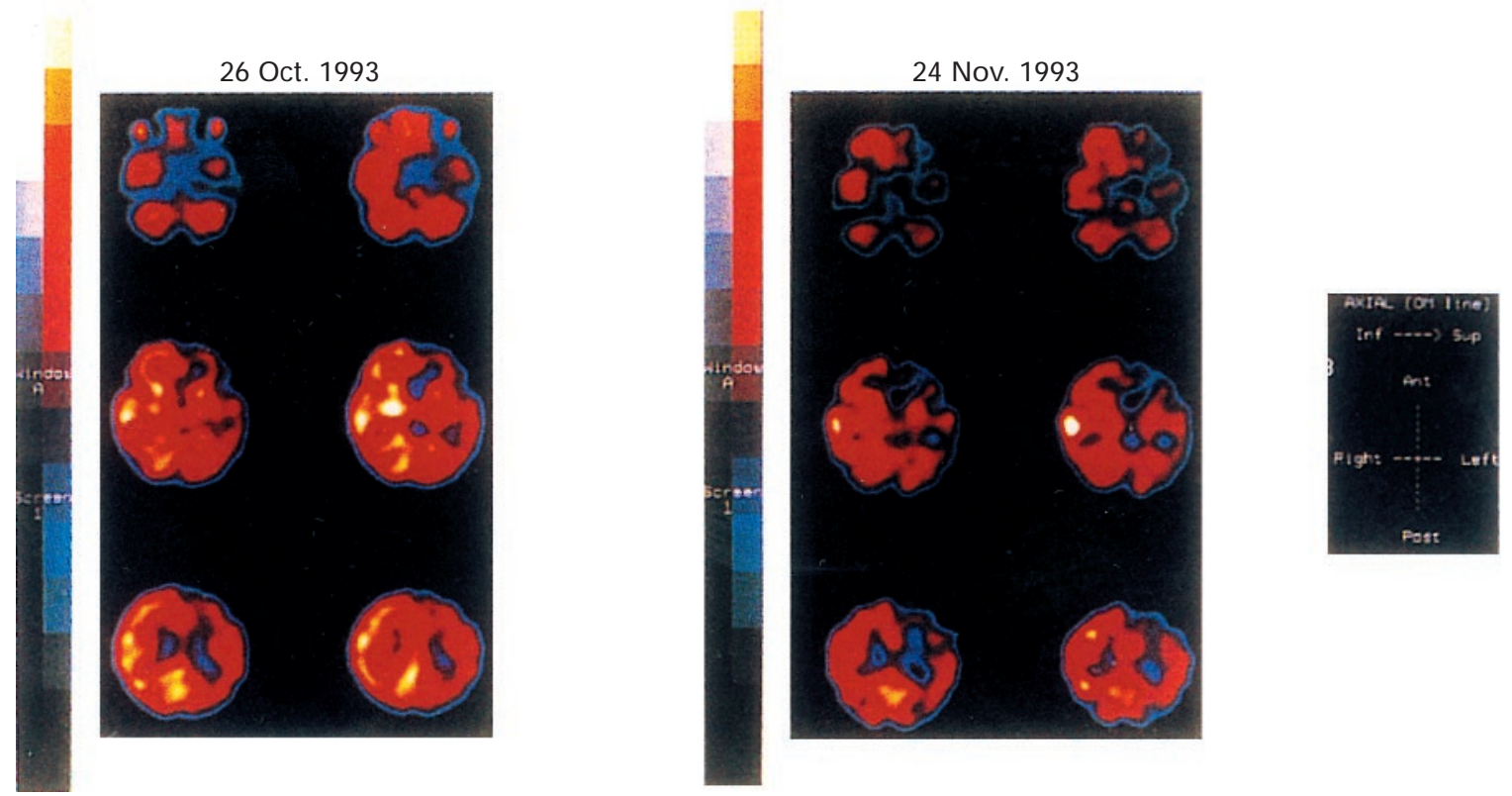

Figure 1. ${ }^{99 \mathrm{M}} \mathrm{Tc}-\mathrm{HM}-\mathrm{PAO}$ SPECT in a patient infected with human herpesvirus-6, showing hyperperfused area of the left hemisphere. From Yanagihara et al, 1995.

immunohistochemistry of both brain biopsy (performed 3 weeks into the course of illness) and brain tissue at autopsy. Ultrastructural study of brain tissue revealed viral particles within oligodendrocytes.

Finally, immunohistochemical staining of brain tissue samples from an immunocompetent 27-yearold woman who died of a subacute demyelinating leukoencephalitis demonstrated widespread active infection with HHV-6 (Carrigan et al, 1996). In all of the postmortem specimens evaluated, the HHV-6infected cells were located within or immediately adjacent to areas of active demyelination and no infected cells were observed in tissue samples free of pathologic changes or in old, highly gliotic plaques. Prior to the retrospective postmortem analysis for HHV-6, the woman had been clinically and histopathologically diagnosed as having acute multiple sclerosis. Discussion of additional evidence suggesting that HHV-6 may play a role in the pathophysiology of multiple sclerosis is presented below.

\section{Detection of HHV-6 in absence of acute CNS \\ disease}

Reports vary on the frequency with which HHV-6 can be detected in the CNS of immunocompetent and immunocompromised patients who do not have acute encephalitis or primary HHV-6 infection. Most studies have detected HHV-6 DNA in the brains of such patients with high frequency. In one report, HHV-6 DNA was detected by PCR in 11
(85\%) of 13 brain tissue specimens obtained within $18 \mathrm{~h}$ of death from 13 adult immunocompetent patients without clinical signs of viral disease (Luppi et al, 1994). Variant analysis was performed in five of the 11 PCR-positive patients and all were determined to be HHV-6 variant A (Luppi et al, 1994).

Additional studies have evaluated possible HHV6 involvement in the CNS of persons with advanced HIV infection (Achim et al, 1994; Knox and Carrigan, 1995; Luppi et al, 1995; Saito et al, 1995). In a study of postmortem pediatric brain tissues from children with progressive AIDS encephalopathy, HHV-6 nucleic acids were detected using in situ hybridization in four $(80 \%)$ of five patients (Saito et al, 1995). Human herpesvirus-6 DNA was detected primarily in oligodendrocytes of the white matter and less frequently in astrocytes, macrophages, microglia and neurons. The HHV-6positive cells did not show evidence of productive HHV-6 infection, as evidenced by a lack of detection of HHV-6 protein products (Saito et al, 1995).

In an investigation of six adults who died of AIDS, four had demyelinating lesions in brain tissue on postmortem examination (Knox and Carrigan, 1995). Immunohistochemical staining demonstrated HHV-6-infected cells in areas of demyelination but not in histologically normal regions of the brains, suggesting active HHV-6 infection in these areas. Three of the four patients had only a few foci of demyelination, while the fourth had diffuse demyelination. The neuropatho- 
logic findings were similar to those from the bone marrow transplant recipient described above (Yanagihara et al, 1995).

In a third study, investigators performed PCR for HHV-6 using brain tissue specimens obtained at necropsy from immunocompetent adult subjects and patients who died of AIDS (Luppi et al, 1995). Human herpesvirus-6-specific sequences were identified in six $(67 \%)$ of nine brain samples from immunocompetent subjects and in four $(57 \%)$ of seven brain samples from AIDS patients. The HHV6 DNA was detected both in gray matter (frontal cortex and basal ganglia) and in periventricular white matter.

While at least one report documents a much lower frequency of HHV-6 detection in the brain of patients dying of advanced HIV infection (Achim et al, 1994), findings from these studies, taken as a whole, affirm the suggestion that HHV-6 is neurotropic and that it establishes latency within the CNS. Additional investigation is required, however, to fully elucidate what role, if any, HHV-6 plays in AIDS encephalopathy.

Human herpesvirus-6 can also cause CNS disease at the level of the spinal cord. The case of an elderly woman with chronic myelopathy with progressive spastic paraparesis has been reported (MacKenzie et al, 1995). At autopsy, widespread demyelination, axonal loss, chronic inflammation and gliosis were demonstrated. Immunohistochemical staining documented the presence of HHV-6 antigens predominantly in astrocytes in regions of white matter degeneration. Human herpesvirus-6 DNA was detected in the abnormal spinal cord tissues as well, suggesting an association between HHV-6 and chronic myelopathy (MacKenzie et al, 1995).

\section{Multiple sclerosis}

Over the years, many microbiologic agents have been proposed as possibly being associated multiple sclerosis (MS). Under scientific scrutiny, each subsequently has been discredited as a causal agent. Thus, recent reports that have suggested that HHV-6 may play a role in the pathogenesis of MS must be approached with caution. Nevertheless, preliminary findings are intriguing, as described below.

Patients with MS have been shown to have higher titers of HHV-6 serum antibody as compared to control patients (Sola et al, 1993; Wilborn et al, 1994). In a recent report, HHV-6 IgM responses were detected in patients with relapsing-remitting MS (RRMS), as compared with patients with chronic progressive MS (CPMS), patients with other neurologic disease (OND), patients with other autoimmune disease (OID) and normal controls (Soldan et al, 1997). Furthermore, HHV-6 DNA was detected in serum of $15(30 \%)$ of 50 patients with MS, but in 0 $(0 \%)$ of 47 non-MS patients (18 healthy controls, 19 patients with OND and ten patients with OID) $(P<0.0001)$ (Soldan et al, 1997). Detection of
HHV-6 DNA in cell-free plasma specimens suggests the presence of active HHV-6 replications in vivo (Huang et al, 1992; Secchiero et al, 1995).

Human herpesvirus-6 DNA has been detected in the CSF of MS patients (Luppi et al, 1994; Liedtke et al, 1995). In one patient with MS who acutely developed inflammation of the CNS and was diagnosed with encephalitis, HHV-6 DNA was detected in the CSF by PCR during the acute episode, whereas it had not been present in CSF collected prior to the encephalitis (Merelli et al, 1996).

As noted above, HHV-6 appears to be present in a majority of adult brains (Luppi et al, 1994), with HHV-6 antigen detectable in neurons and glial cells (Challoner et al, 1995). However, in a study of the brains of MS patients, HHV-6 antigen was also found in nuclei of oligodendrocytes associated with the MS plaques (Challoner et al, 1995). This investigation utilized representational difference analysis (RDA) to detect a DNA sequence in brain tissue of MS patients that was shown to be $99.4 \%$ identical to the major DNA binding protein gene of HHV-6. While examination of 86 brain specimens from both MS patients and controls demonstrated that HHV-6 was present in $>70 \%$ of specimens, nuclear staining of oligodendrocytes with two monoclonal antibodies against HHV-6 was observed in MS cases only but not in controls. Furthermore, in MS cases this staining was observed around plaques more frequently than in uninvolved white matter. Prominent cytoplasmic staining of neurons occurred in gray matter around plaques in MS patients, although neurons expressing HHV-6 were also found in certain controls (Challoner et al, 1995).

Taken together, the results of these studies are titillating. However, other reports have failed to detect serologic (Nielsen et al, 1997) or virologic (Sanders et al, 1996; Martin et al, 1997; Merelli et al, 1997) evidence of an association between HHV-6 and MS. As such, definitive proof of a role for HHV6 in the pathogenesis of MS awaits further study.

\section{Infection in immunocompromised patients}

Reactivation of HHV-6 from latency can occur between 2 weeks and 3 months following organ transplantation. The precise frequency of such episodes of viral reactivation is contingent upon several things, including the type of transplant and, likely, the degree of immunosuppression. Human herpesvirus- 6 has been implicated as a cause of disease in renal transplant recipients (Asano et al, 1989b; Morris et al, 1989; Gudnason et al, 1991; Yoshikawa et al, 1992c), bone marrow transplant recipients (Asano et al, 1991b; Yoshikawa et al, 1991; Knox and Carrigan, 1992; Rosenfeld et al, 1995; Knox and Carrigan, 1996b) and liver transplant recipients (Ward et al, 1989; Sutherland et al, 1991; Singh et al, 1995). Neurologic disorders 
attributable to HHV-6 have been reported in bone marrow (Yanagihara et al, 1995) and liver transplant patients (Ward et al, 1989; Sutherland et al, 1991; Singh et al, 1995) and include seizures, encephalopathy and encephalitis.

Investigations of HHV-6 in HIV infected patients have yielded conflicting results. Some studies have suggested a role for HHV-6 co-infection in the progression of HIV disease (Chen et al, 1992; Corbellino et al, 1993; Fairfax et al, 1994; Knox and Carrigan, 1994; Blázquez et al, 1995; Clark et al, 1996; Knox and Carrigan, 1996a), while others have found no correlation between HHV-6 infection and the course of HIV infection (Brown et al, 1988a; Fox et al, 1988; Spira et al, 1990; Essers et al, 1991; Gautheret et al, 1995). Possible CNS involvement by HHV-6 in HIV infected persons is discussed above.

\section{Conclusion}

The rapid pace of discovery following the identification of HHV-6 just over a decade ago is quite remarkable. The neuroinvasive potential of HHV-6

\section{References}

Ablashi DV, Lusso P, Hung CL, Salahuddin SZ, Josephs SF, Llana T, Kramarshy B, Biberfeld P, Markham PD, Gallo RC (1988). Utilization of human hematopoietic cell lines for the propagation and characterization of HBLV (human herpesvirus 6). Int J Cancer 42: $787-$ 791.

Ablashi DV, Balachandran N, Josephs SF, Hung CL, Krueger GR, Kramarsky B, Salahuddin SZ, Gallo RC (1991). Genomic polymorphism, growth properties and immunologic variations in human herpesvirus-6 isolates. Virology 184: 545-552.

Ablashi D, Agut H, Berneman Z, et al. (1993). Human herpesvirus-6 strain groups: a nomenclature. Arch Virol 129: $363-366$.

Achim CL, Wang R, Miners DK, Wiley CA (1994). Brain viral burden in HIV infection. I Neuropathol Exp Neurol 53: 284-294.

Akashi K, Eizuru Y, Sumiyoshi Y, Minematsu T, Hara S, Harada M, Kikuchi M, Niho Y, Minamishima Y (1993). Brief report: severe infectious mononucleosislike syndrome and primary human herpesvirus 6 infection in an adult. $N$ Engl J Med 329: 168-171.

Asano Y, Suga S, Yoshikawa T, Urisu A, Yazaki T (1989a). Human herpesvirus type 6 infection (exanthem subitum) without fever. J Pediatr 115: $264-$ 265.

Asano Y, Yoshikawa T, Suga S, Yazaki T, Hirabayashi S, Ono Y, Tsuzuki K, Oshima S (1989b) Human herpesvirus 6 harbouring in kidney. Lancet 2: 1391.

Asano Y, Nakashima T, Yoshikawa T, Suga S, Yazaki T (1991a). Severity of human herpesvirus-6 viremian and clinical findings in infants with exanthem subitum. J Pediatr 118: 891-895. has been demonstrated in both immunocompetent and immunocompromised individuals. Furthermore, HHV-6 has been associated clinically with a wide array of neurologic manifestations in these patients. The knowledge amassed to date detailing the CNS manifestations of HHV-6 largely has been built on small case reports and retrospective studies, which have prepared the groundwork for larger prospective investigations. Controlled investigations of antiviral agents with activity against HHV-6 are now warranted to define which patients will benefit from antiviral administration, both as active and suppressive therapy. In the conduct of these studies, additional knowledge of the natural history of HHV-6 in the CNS will be acquired.

Grant support: This work was supported in part by the Antiviral Research Branch of the National Institute of Allergy and Infectious Diseases (NO1AI-62554; DWK, RJW); a Program Project Grant (PO1 AI 24009; RJW); an Unrestricted Grant in Infectious Diseases from Bristol-Myers Squibb (RJW); and by grants from the General Clinical Research Program (RR-032), and the State of Alabama.

Asano Y, Yoshikawa T, Suga S, Nakashima T, Yazaki T, Fukuda M, Kojima S, Matsuyama T (1991b). Reactivation of herpesvirus type 6 in children receiving bone marrow transplants for leukemia. N Engl J Med 324: 634-635.

Asano Y, Yoshikawa T, Kajita Y, Ogura R, Suga S, Yazaki T, Nakashima T, Yamada A, Kurata T (1992). Fatal encephalitis/encephalopathy in primary human herpesvirus-6 infection. Arch Dis Child 67: 14841485.

Asano Y, Yoshikawa T, Suga S, Kobayashi I, Nakashima T, Yazaki T, Kajita Y, Ozaki T (1994). Clinical features of infants with primary human herpesvirus 6 infection (exanthem subitum, roseola infantum). Pediatrics 93: $104-108$.

Aubin J-T, Collandre H, Candotti D, Ingrand D, Rouzioux C, Burgard M, Richard S, Huraux J-M, Agut H (1991). Several groups among human herpesvirus-6 strains can be distinguished by Southern blotting and polymerase chain reaction. J Clin Microbiol 29: 367 372.

Aubin J-T, Agut H, Collandre H, Yamanishi K, Chandran B, Montagnier L, Huraux J-M (1993). Antigenic and genetic differentiation of two putative types of human herpesvirus-6. J Virol Methods 41: 223-234.

Barone SR, Kaplan MH, Krilov LR (1995). Human herpesvirus-6 infection in children with first febrile seizures. J Pediatr 127: 95-97.

Berenberg W, Wright S, Janeway CA (1949). Roseola infantum (exanthem subitum). $N$ Engl J Med 241: $253-259$. 
Black JB, Sanderlin KC, Goldsmith CS, Gary HE, Lopez C, Pellett PE (1989). Growth properties of human herpesvirus-6 strain Z29. J Virol Methods 26: $133-$ 145.

Blázquez VM, Madueño JA, Jurado R, Fernández-Arcás N, Muñoz E (1995). Human herpesvirus-6 and the course of human immunodeficiency virus infection. $J$ Acquir Immune Defic Syndr 9: 389-394.

Brown NA, Kovacs A, Lui CR, Hur C, Zaia JA, Mosley JW (1988a). Prevalence of antibody to human herpesvirus 6 among blood donors infected with HIV. Lancet 2: 1146.

Brown NA, Sumaya CV, Liu C-R, Ench Y, Kovacs A, Coronesi M, Kaplan MH (1988b). Fall in human herpesvirus 6 seropositivity with age. Lancet 2: 396.

Burnstine RC, Paine RS (1959). Residual encephalopathy following roseola infantum. Am J Dis Child 98: 144152.

Carrigan DR, Harrington D, Knox KK (1996). Subacute leukoencephalitis caused by CNS infection with human herpesvirus-6 manifesting as acute multiple sclerosis. Neurology 47: 145-148.

Caserta MT, Hall CB, Schnabel K, McIntyre K, Long C, Costanzo M, Dewhurst S, Insel R, Epstein LG (1994). Neuroinvasion and persistence of human herpesvirus 6 in children. J Infect Dis 170: 1586-1589.

Challoner PB, Smith KT, Parker JD, MacLeod DL, Coulter SN, Rose TM, Schultz ER, Bennett JL, Garber RL, Chang M, Schad PA, Stewart PM, Nowinski RC, Brown JP, Burmer GC (1995). Plaque-associated expression of human herpesvirus 6 in multiple sclerosis. Proc Natl Acad Sci USA 92: 7440-7444.

Chen H, Pesce AM, Carbonari M, Ensoli F, Cherchi M, Campitelli G, Sbarigia D, Luzi G, Aiuti F, Fiorilli M (1992). Absence of antibodies to human herpesvirus-6 in patients with slowly-progressive human immunodeficiency virus type 1 infection. Eur J Epidemiol 8: $217-221$.

Chou S, Marousek GI (1994). Analysis of interstrain variation in a putative immediate-early region of human herpesvirus 6 DNA and definition of variantspecific sequences. Virology 198: $370-376$.

Clark DA, Ait-Khaled M, Wheeler AC, Kidd IM, McLaughlin JE, Johnson MA, Griffiths PD, Emery VC (1996). Quantification of human herpesvirus 6 in immunocompetent persons and post-mortem tissues from AIDS patients by PCR. J Gen Virol 77: 22712275 .

Cone RW, Huang ML, Ashley R, Corey L (1993). Human herpesvirus 6 DNA in peripheral blood cells and saliva from immunocompetent individuals. $J$ Clin Microbiol 31: 1262-1267.

Corbellino M, Lusso P, Gallo RC, Parravicini C, Galli M, Moroni M (1993). Disseminated human herpesvirus 6 infection in AIDS. Lancet 342: 1242.

Cuende JI, Ruiz J, Civeira MP, Prieto J (1994). High prevalence of HHV-6 DNA in peripheral blood mononuclear cells of health individuals detected by nestedPCR. J Med Virol 43: 115-118.

Dewhurst S, Chandran B, McIntyre K, Schnabel K, Hall CB (1992). Phenotypic and genetic polymorphisms among human herpesvirus-6 isolates from North American infants. Virology 190: 490-493.
Dewhurst S, McIntyre K, Schnabel K, Hall CB (1993). Human herpesvirus 6 (HHV-6) variant B accounts for the majority of symptomatic primary HHV-6 infections in a population of U.S. infants. J Clin Microbiol 31: $416-418$.

Downing RG, Sewankambo N, Serwadda D, Honess R, Crawford D, Jarrett R, Griffin BE (1987). Isolation of human lymphotropic herpesviruses from Uganda. Lancet ii: 390.

Drobyski WR, Knox KK, Majewski D, Carrigan DR (1994). Brief report: fatal encephalitis due to variant B human herpesvirus-6 infection in a bone marrow-transplant recipient. $N$ Engl J Med 330: 1356-1360.

Dubedat S, Kappagoda N (1989). Hepatitis due to human herpesvirus-6. Lancet 2: 1463-1464.

Essers S, Schwinn A, ter Meulen J, von Lips H, Dietz K, Mhalu FS, Shao J, ter Meulen V (1991). Seroepidemiological correlations of antibodies to human herpesviruses and human immunodeficiency virus type 1 in African patients. Eur J Epidemiol 7: 658664.

Fairfax MR, Schacker T, Cone RW, Collier AC, Corey L (1994). Human herpesvirus 6 DNA in blood cells of human immunodeficiency virus-infected men: correlation of high levels with high CD4 cell counts. J Infect Dis 169: $1342-1345$.

Farr TJ, Harnett GB, Pietroboni GR, Bucens MR (1990). The distribution of antibodies to HHV-6 compared with other herpesviruses in young children. Epidemiol Infect 105: 603-607.

Fox J, Briggs M, Tedder RS (1988). Antibody to human herpesvirus 6 in HIV-1 positive and negative homosexual men. Lancet 2: 396-397.

Fox JD, Briggs M, Ward PA, Tedder RS (1990). Human herpesvirus 6 in salivary glands. Lancet 336: $590-$ 593.

Fenkel N, Schirmer EC, Katsafanas G, June CH (1990). Tcell activation is required for efficient replication of human herpesvirus 6. J Virol 64: 4598-4602.

Gautheret A, Aubin JT, Fauveau V, Rozenbaum W, Huraux JM, Agut $H$ (1995). Rate of detection of human herpesvirus-6 at different stages of HIV infection. Eur J Clin Microbiol Infect Dis 14: 820-824.

Gompels UA, Carrigan D, Carss AL, Arno J (1993). Two groups of human herpesvirus-6 identified by sequence analyses of laboratory strains and variants from Hodgkins lymphoma and bone marrow transplant patients. J Gen Virol 74: 613-622.

Gopal MR, Thomson BJ, Fox J, Tedder RS, Honess RW (1990). Detection by PCR of HHV-6 and EBV DNA in blood and oropharynx of healthy adults and HIVseropositives. Lancet 335: 1598-1599.

Gudnason T, Dunn DL, Brown NA, Balfour HH (1991). Human herpes virus 6 infections in hospitalized renal transplant recipients. Clin Transpl 5: 359-364.

Hall CB, Long CE, Schnabel KC, Caserta MT, McIntyre KM, Costanzo MA, Knott A, Dewhurst S, Insel RA, Epstein LG (1994). Human herpesvirus-6 infection in children: a prospective study of complications and reactivation. $N$ Engl J Med 331: $432-438$.

Harnett GB, Farr TJ, Pietroboni GR, Bucens MR (1990) Frequent shedding of human herpesvirus 6 in saliva. $J$ Med Virol 30: 128-130. 
He J, McCarthy M, Zhou Y, Chandran B, Wood C (1996). Infection of primary human fetal astrocytes by human herpesvirus 6. J Virol 70: 1296-1300.

Hellstrom B, Vahlquist B (1951). Experimental inoculation of roseola infantum. Acta Paediatrica 40: 189197.

Huang LM, Lee CY, Lee PI, Chen JM, Wang PJ (1991). Meningitis caused by human herpesvirus-6. Arch Dis Child 66: $1443-1444$.

Huang LM, Kuo PF, Lee CY, Chen JY, Liu MY, Yang CS (1992). Detection of human herpesvirus-6 DNA by polymerase chain reaction in serum or plasma. $J$ Med Virol 38: $7-10$.

Ishiguro N, Yamada S, Takahashi T, Takahashi Y, Togashi T, Okuno T, Yamanishi K (1990). Meningoencephalitis associated with HHV-6 related exanthem subitum. Acta Paediatr Scand 79: 987-989.

Jarrett RF, Clark DA, Josephs SF, Onions DE (1990). Detection of human herpesvirus-6 DNA in peripheral blood and saliva. J Med Virol 32: 72-76.

Jee SH, Long CE, Schnabel KC, Sehgal N, Epstein LG, Hall CB (1998). Risk of recurrent seizures after a primary HHV-6 induced febrile seizure. Pediatr Infect Dis J 17: $43-48$.

Josephs SF, Salahuddin SZ, Ablashi DV, Schachter F, Wong-Staal F, Gallo RC (1986). Genomic analysis of the human B-lymphotropic virus (HBLV). Science 234: $601-603$.

Kasolo FC, Mpabalwani E, Gompels UA (1997). Infection with AIDS-related herpesviruses in human immunodeficiency virus-negative infants and endemic childhood Kaposi's sarcoma in Africa. J Gen Virol 78: $847-856$.

Kawaguchi S, Suga S, Kozawa T, Nakashima T, Yoshikawa T, Asano Y (1992). Primary human herpesvirus-6 infection (exanthem subitum) in the newborn. Pediatrics 90: 628-630.

Kempe CH, Shaw EB, Jackson JR, Silver HK (1950). Studies on the etiology of exanthema subitum (roseola infantum). J Pediatr 37: 561-568.

Knowles WA, Gardner SD (1988). High prevalence of antibody to human herpesvirus- 6 and seroconversion associated with rash in two infants. Lancet 2: 912913.

Knox KK, Carrigan DR (1992). In vitro suppression of bone marrow progenitor cell differentiation by human herpesvirus 6 infection. J Infect Dis 165: 925-929.

Knox KK, Carrigan DR (1994). Disseminated active HHV6 infections in patients with AIDS. Lancet 343: 577578 .

Knox KK, Carrigan DR (1995). Active human herpesvirus (HHV-6) infection of the central nervous system in patients with AIDS. J Acquired Immune Defic Syndr Hum Retroviruses 9: 69-73.

Knox KK, Harrington DP, Carrigan DR (1995). Fulminant human herpesvirus six encephalitis in a human immunodeficiency virus-infected infant. I Med Virol 45: $288-292$.

Knox KK, Carrigan DR (1996a). Active HHV-6 infection in the lymph nodes of HIV-infected patients: in vitro evidence that HHV-6 can break HIV latency. J Acquir Immune Defic Syndr 11: 370-378.

Knox KK, Carrigan DR (1996b). Chronic myelosuppression associated with persistent bone marrow infection due to human herpesvirus 6 in a bone marrow transplant recipient. Clin Infect Dis 22: 174-175.
Kondo K, Nagafuji H, Hata A, Tomomori C, Yamanishi K (1993). Association of human herpesvirus 6 infection of the central nervous system with recurrence of febrile convulsions. J Infect Dis 167: 1197-1200.

Krueger GRF, Wassermann K, DeClerck LS, Stevens WJ, Bourgeois N, Ablashi DV, Josephs SF, Balachandran N (1990). Latent herpesvirus-6 in salivary and bronchial glands. Lancet 336: $1255-1256$.

Kisuhara K, Ueda K, Miyazaki C, Okada K, Tokugawa K (1992). Attack rate of exanthem subitum in Japan. Lancet 340: 482.

Leach CT, Sumaya CV, Brown NA (1992). Human herpesvirus-6: clinical implications of a recently discovered, ubiquitous agent. J Pediatr 121: 173-181.

Levine PH, Jahan N, Murari P, Manak M, Jaffe ES (1992). Detection of human herpesvirus 6 in tissues involved by sinus histiocytosis with massive lymphadenopathy (Rosai-Dorfman disease). J Infect Dis 166: 291-295.

Levy JA, Ferro F, Lennette ET, Oshiro L, Poulin L (1990a). Characterization of a new strain of HHV-6 (HHV-6SF) recovered from the saliva of an HIVinfected individual. Virology 178: $113-121$.

Levy JA, Greenspan D, Ferro F, Lennette ET (1990b). Frequent isolation of HHV-6 from saliva and high seroprevalence of the virus in the population. Lancet 335: $1047-1050$

Liedtke W, Malessa R, Faustmann PM, Eis-Hübinger AM (1995). Human herpesvirus 6 polymerase chain reaction findings in human immunodeficiency virus associated neurological disease and multiple sclerosis. J Neuro Virol 1: 253-258.

Lopez C, Pellett P, Stewart J, Goldsmith C, Sanderlin K, Black J, Warfield D, Feorino P (1988). Characteristics of human herpesvirus-6. J Infect Dis 157: 1271-1273.

Luppi M, Barozzi P, Maiorana A, Marasca R, Torelli G (1994). Human herpesvirus 6 infection in normal human brain tissue. J Infect Dis 169: 943-944.

Luppi M, Barozzi P, Maiorana A, Marasca R, Trovato R, Fano R, Ceccherini-Nelli L, Torelli G (1995). Human herpesvirus-6: a survey of presence and distribution of genomic sequences in normal brain and neuroglial tumors. I Med Virol 47: 105-111.

Lusso P, Markham PD, Tschachler E, Veronese FM, Salahuddin SZ, Ablashi DV, Pahwa S, Krohn K, Gallo RC (1988). In vitro cellular tropism of human Blymphotropic virus (human herpesvirus-6). J Exp Med 167: $1659-1670$

Lusso P, Gallo RC, DeRocco SE, Markham PD (1989). CD4 is not the membrane receptor for HHV-6. Lancet 1: 730 .

Lusso P, Malnati MS, Garzino-Demo A, Crowley RW, Long EO, Gallo RC (1993). Infection of natural killer cells by human herpesvirus 6. Nature 362: 458-462.

MacKenzie IR, Carrigan DR, Wiley CA (1995). Chronic myelopathy associated with human herpesvirus-6. Neurology 45: 2015-2017.

Martin C, Enbom M, Soderstrom M, Fredrikson S, Dahl H, Lycke J, Bergstrom T, Linde A (1997). Absence of seven human herpesviruses, including HHV-6, by polymerase chain reaction in CSF and blood from patients with multiple sclerosis and optic neuritis. Acta Neurol Scand 95: 280-283.

McCullers JA, Lakeman FD, Whitley RJ (1995). Human herpesvirus 6 is associated with focal encephalitis. Clin Infect Dis 21: 571-576. 
Merelli E, Sola P, Barozzi P, Torelli G (1996). An encephalitic episode in a multiple sclerosis patient with human herpesvirus 6 latent infection. J Neurol Sci 137: 42-46.

Merelli E, Bedin R, Sola P, Barozzi P, Mancardi GL, Ficarra G, Franchini G (1997). Human herpes virus 6 and human herpes virus 8 DNA sequences in brains of multiple sclerosis patients, normal adults and children. J Neurol 244: 450-454.

Moller KL (1956). Exanthema subitum and febrile convulsions. Acta Paediatr 45: 534-540.

Morris DJ, Littler E, Arrand JR, Jordan D, Mallick NP, Johnson RW (1989). Human herpesvirus 6 infection in renal-transplant recipients. N Engl J Med 320: 15601561.

Niederman JC, Liu CR, Kaplan MH, Brown NA (1988). Clinical and serological features of human herpesvirus-6 infection in three adults. Lancet 2: 817-818.

Nielsen L, Larsen AM, Munk M, Vestergaard BF (1997). Human herpesvirus-6 immunoglobulin G antibodies in patients with multiple sclerosis. Acta Neurol Scand Supp 169: $76-78$.

Novoa LJ, Nagra RM, Nakawatase T, Edwards-Lee T, Tourtellotte WW, Cornford ME (1997). Fulminant demyelinating encephalomyelitis associated with productive HHV-6 infection in an immunocompetent adult. J Med Virol 52: $301-308$.

Okada K, Ueda K, Kusuhara K, Miyazaki C, Tokugawa K, Hirose M, Yamanishi K (1993). Exantema subitum and human herpesvirus 6 infection: clinical observations in fifty-seven cases. Pediatr Infect Dis J 12: 204-208.

Patnaik M, Peter JB (1995). Intrathecal synthesis of antibodies to human herpesvirus 6 early antigen in patients with meningitis/encephalitis. Clin Infect Dis 21: $715-716$.

Pellett PE, Black JB (1996). Human herpesvirus 6. In Fields Virology. Fields BN, Knipe DM, Howley PM, Chanock RM, Melnick JL, Monath, TP, Roizman B, Straus SE, (eds). Lippincott-Raven Publishers: Philadelphia, pp 2587-2608.

Portolani M, Cermelli C, Moroni A, Bertolani MF, DiLuca D, Cassai E, Sabbatini AM (1993). Human herpesvirus6 infections in infants admitted to hospital. J Med Virol 39: $146-151$.

Posson DD (1949). Exanthem subitum (roseola infantum) complicated by prolonged convulsions and hemiplegia. J Pediatr 35: 235-236.

Pruksananonda P, Hall CB, Insel RA, McIntyre K, Pellett PE, Long CE, Schnabel KC, Pincus PH, Stamey FR, Dambaugh TR, Stewart JA (1992). Primary human herpesvirus 6 infection in young children. $N$ Engl $J$ Med 326: $1445-1450$.

Ranger S, Patillaud S, Denis F, Himmich A, Sangare A, M'Boup S, Itoua-N'Gaporo A, Prince-David M, Chout R, Cevallos R (1991). Seroepidemiology of human herpesvirus-6 in pregnant women from different parts of the world. J Med Virol 34: 194-198.

Rosenfeld CS, Rybka WB, Weinbaum D, Carrigan DR, Knox KK, Andrews DF, Shadduck RK (1995). Late graft failure due to dual bone marrow infection with variants A and B of human herpesvirus-6. Exper Hematol 23: 626-629.

Saito Y, Sharer LR, Dewhurst S, Blumberg BM, Hall CB, Epstein LG (1995). Cellular localization of human herpesvirus-6 in brains of children with AIDS encephalopathy. J NeuroVirol 1: 30-39.
Salahuddin SZ, Ablashi DV, Markham PD, Josephs SF, Sturzenegger S, Kaplan M, Halligan G, Biberfeld P, Wong-Staal F, Kramarsky B, Gallo RC (1986). Isolation of a new virus, HBLV, in patients with lymphoproliferative disorders. Science 234: 596-601.

Sanders VJ, Felisan S, Waddell A, Tourtellotte WW (1996). Detection of herpesviridae in postmortem multiple sclerosis brain tissue and controls by polymerase chain reaction. J NeuroVirol 2: 249-258.

Secchiero P, Carrigan DR, Asano Y, Benedetti L, Crowley RW, Komaroff AL, Gallo RC, Lusso P (1995). Detection of human herpesvirus 6 in plasma of children with primary infection and immunosuppressed patients by polymerase chain reaction. J Infect Dis 171: 273-280.

Segondy M, Astruc J, Atoui N, Echenne B, Robert C, Agut $H$ (1992). Herpesvirus 6 infection in young children. $N$ Engl J Med 327: 1099-1100.

Singh N, Carrigan DR, Gayowski T, Singh J, Marino IR (1995). Variant B human herpesvirus-6 associated febrile dermatosis with thrombocytopenia and encephalopathy in a liver transplant recipient. Transplantation 60: $1355-1357$.

Sloots TP, Mackay IM, Carroll P (1993). Meningoencephalitis in adult with human herpesvirus-6 infection. Med J Aust 159: 838.

Sobue R, Miyazaki H, Okamoto M, Hirano M, Yoshikawa T, Suga S, Asano Y (1991). Fulminant hepatitis in primary human herpesvirus-6 infection. $N$ Engl J Med 324: 1290.

Sola P, Merelli E, Marasca R, Poggi M, Luppi M, Montorsi M, Torelli G (1993). Human herpesvirus 6 and multiple sclerosis: survey of anti-HHV-6 antibodies by immunofluorescence analysis and of viral sequences by polymerase chain reaction. I Neurol Neurosurg Psych 56: $917-919$.

Soldan SS, Berti R, Salem N, Secchiero P, Flammand L, Calabresi PA, Brennan MB, Maloni HW, McFarland HF, Lin HC, Patnaik M, Jacobson S (1997). Association of human herpes virus 6 (HHV-6) with multiple sclerosis: Increased IgM response to HHV-6 early antigen and detection of serum HHV-6 DNA. Nature Med 3: $1394-1397$.

Spira TJ, Bozeman LH, Sanderlin KC, Warfield DT, Feorino PM, Holman RC, Kaplan JE, Fishbein DB, Lopez C (1990). Lack of correlation between human herpesvirus-6 infection and the course of human immunodeficiency virus infection. J Infect Dis 161: $567-570$.

Steeper TA, Horwitz CA, Ablashi DV, Salahuddin SZ, Saxinger C, Saltzman R, Schwartz B (1990). The spectrum of clinical and laboratory findings resulting from human herpesvirus-6 (HHV-6) in patients with mononucleosis-like illnesses not resulting from Epstein-Barr virus or cytomegalovirus. Am J Clin Pathol 93: $776-783$.

Stettner-Gloning R, Jager G, Gloning $H$, Pontz BF, Emmrich $\mathrm{P}$ (1992). Lymphadenopathy in connection with human herpes virus type 6 (HHV-6) infection. Clin Investig 70: 59-62.

Suga S, Yoshikawa T, Asano Y, Yazaki T, Hirata S (1989). Human herpesvirus-6 infection (exanthem subitum) without rash. Pediatrics 83: $1003-1006$. 
Suga S, Yoshikawa T, Asano Y, Kozawa T, Nakashima T, Kobayashi I, Yazaki T, Yamamoto H, Kajita Y, Ozaki T, Nishimura Y, Yamanaka T, Yamada A, Imanishi J (1993). Clinical and virological analyses of 21 infants with exanthem subitum (roseola infantum) and central nervous system complications. Ann Neurol 33: 597603.

Sutherland S, Christofinis G, O’Grady J, Williams R (1991). A serological investigation of human herpesvirus 6 infections in liver transplant recipients and the detection of cross-reacting antibodies to cytomegalovirus. J Med Virol 33: 172-176.

Takahashi K, Sonoda S, Kawakami K, Miyata K, Oki T, Nagata T, Okuno T, Yamanishi K (1988). Human herpesvirus 6 and exanthem subitum. Lancet i: 1463.

Takahashi K, Sonoda S, Higashi K, Kondo T, Takahashi H, Takahashi M, Yamanishi K (1989). Predominant CD4 T-lymphocyte tropism of human herpesvirus 6related virus. J Virol 63: 3161-3163.

Tedder RS, Briggs M, Cameron CH, Honess R, Robertson D, Whittle H (1987). A novel lymphotropic herpesvirus. Lancet 2: 390-392.

Teo IA, Griffin BE, Jones MD (1991). Characterisation of the DNA polymerase gene of human herpesvirus-6. $J$ Virol 65: $4670-4680$.

Ueda K, Kusuhara K, Hirose M, Okada K, Miyazaki C, Tokugawa K, Nakayama M, Yamanishi K (1989). Exanthem subitum and antibody to human herpesvirus-6. J Infect Dis 159: 750-752.

Ward KN, Gray JJ, Efstathiou S (1989). Brief report: primary human herpesvirus 6 infection in a patient following liver transplantation from a seropositive donor. J Med Virol 28: 69-72.

Ward KN, Gray JJ (1994). Primary human herpesvirus-6 infection is frequently overlooked as a cause of febrile fits in young children. J Med Virol 42: 119-123.

Wilborn F, Schmidt CA, Brinkmann V, Jendroska K, Oettle H, Siegert W (1994). A potential role for human herpesvirus type 6 in nervous system disease. J Neuroimmunol 49: 213-214.

Yadav M, Umamaheswari S, Ablashi DV (1990). Low prevalence of antibody to human herpesvirus-6 (HHV6) in Kadazans. Southeast Asian J Trop Med Public Health 21: 259-263.
Yamanishi K, Okuno T, Shiraki K, Takahashi M, Kondo $\mathrm{T}$, Asano Y, Kurata T (1988). Identification of human herpesvirus-6 as a causal agent for exanthem subitum. Lancet 1: $1065-1067$.

Yamanishi K, Kondo K, Mukai T, Kondo T, Nagafuji H, Kato T, Okuno T, Kurata $\mathrm{T}$ (1992). Human herpesvirus-6 (HHV-6) infection in the central nervous system. Acta Paediatr Jpn 34: $337-343$.

Yanagihara K, Tanaka-Taya K, Itagaki Y, Toribe Y, Arita K, Yamanishi K, Okada S (1995). Human herpesvirus 6 meningoencephalitis with sequelae. Pediatr Infect Dis J 14: $240-242$.

Yoshikawa T, Suga S, Asano Y, Yazaki T, Kodama H, Ozaki T (1989). Distribution of antibodies to a causative agent of exanthem subitum (human herpesvirus-6) in healthy individuals. Pediatrics 84: 675677.

Yoshikawa T, Suga S, Asano Y, Nakashima T, Yazaki T, Sobue R, Hirano M, Fukuda M, Kojima S, Matsuyama $\mathrm{T}$ (1991). Human herpesvirus-6 infection in bone marrow transplantation. Blood 78: 1381-1384.

Yoshikawa T, Nakashima T, Asano Y, Suga S, Yazaki T, Kojima S, Mukai T, Yamanishi K (1992a). Endonuclease analyses of DNA of human herpesvirus-6 isolated from blood before and after bone marrow transplantation. J Med Virol 37: 228-231.

Yoshikawa T, Nakashima T, Suga S, Asano Y, Yazaki T, Kimura H, Morishima T, Kondo K, Yamanishi K (1992b). Human herpesvirus-6 DNA in cerebrospinal fluid of a child with exanthem subitum and meningoencephalitis. Pediatrics 89: 888-890.

Yoshikawa T, Suga S, Asano Y, Nakashima T, Yazaki T, Ono Y, Fujita T, Tsuzuki K, Sugiyama S, Oshima S (1992c). A prospective study of human herpesvirus-6 infection in renal transplantation. Transplantation 54: $879-883$

Yoshiyama H, Suzuki E, Yoshida T, Kajii T, Yamamoto N (1990). Role of human herpesvirus 6 infection in infants with exanthema subitum. Pediatr Infect Dis J 9: $71-74$. 